\title{
Alcohol use disorder identification test use in Muslim countries
}

\author{
A Al Mousawi.
}

PhD student in Chester University and Lecturer in Karbala Medical College.

Correspondence email: 1223159@chester.ac.uk or aalmousawi1@hotmail. com

\begin{abstract}
Background: Although alcohol consumption rates are low in the Middle East, there are pockets of high risk alcohol consumption especially among the youth. However, the main problem is the absence of trusted statistics related to alcohol use in these countries. This study is aimed at finding the possible bias in using Alcohol Use Identification Test (AUDIT) questionnaire among undergraduates in Karbala/Iraq and to determine alcohol consumption rates and the potential predictors.

Material and methods: A random sample ( $\mathrm{n}=5446$ students) answered a questionnaire based on AUDIT. The study objectives were to determine the effect of socio-cultural contexts on validity of AUDIT in a Muslim country. The analysis used descriptive and chi-squares test and regression analysis to assess significant associations at $\mathrm{p}<0.001$ level.

Results: Biased AUDIT findings might be estimated due to the high rates of guilt (54\%) or knowing that others care about alcohol consumption (49\%). Alcohol consumption lifetime incidence rate was $2 \%$ and was higher among male smokers. Risky drinking patterns was high (56\%); however this might be biased due to socio-cultural reasons.

Conclusion: AUDIT use should consider socio-cultural environments. Alcohol consumption among university students is low as similar to the rates reported in neighbouring countries such as Jordan and Turkey. Risky drinking behaviour was alarmingly high which suggests that socio-cultural environment need should be considered in interpreting AUDIT results.
\end{abstract}




\section{إستخدام إختبار الكثف عن إضطرابات تعاطي الكحول في الاول الإسلامية}

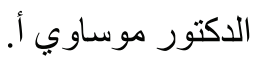

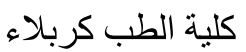

الملخص:

لمحة عن الموضوع:ر غم أن نسب استهلاك المشروبات الكحولية منخفض في منطقة الثرق الأوسط إلا أنه إنها

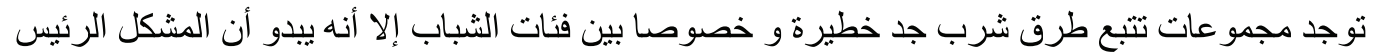

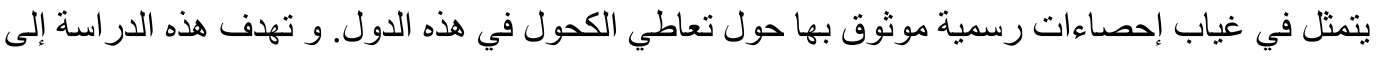

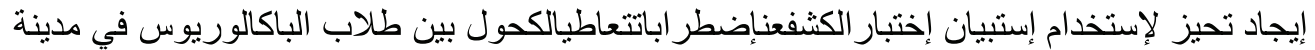
كربلاء بالعراق لتحديدنسب استهلاك الكحول و المتنبآت المحتملة.

المادة و الطريقة: قامت عينة أختيرت بطريقة عشو ائية تماما (طالب n=5446) بالإجابة بشكل طو عي عن

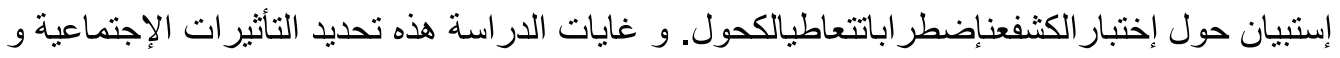

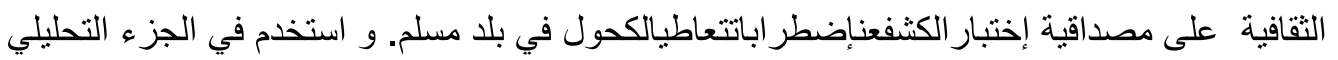
الطريقة إختبار ات "كاي مربع" الوصفية و التحليل التراجعي لتقييم الثر اكات الهامة على مسنوى

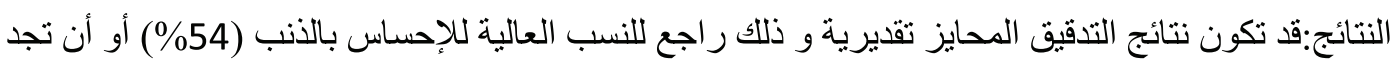

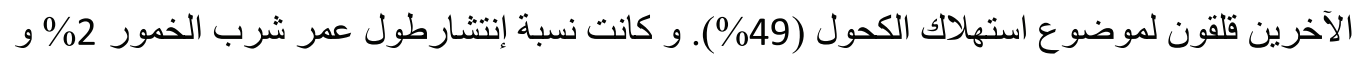

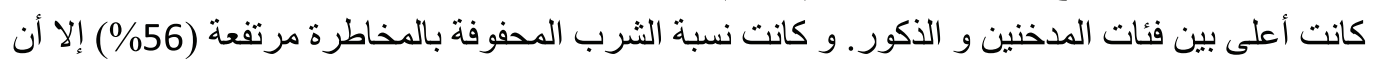
هذه النسبة قد تكون متحيزة و ذلك راج راجع لأسباب إجتماعية و ثنقافية.

الخلاصة: يجب على مستخدميإختبار الكثفعنإضطر اباتتعاطيالكحول ان يأخدو ا في عين الحسبان المعايير

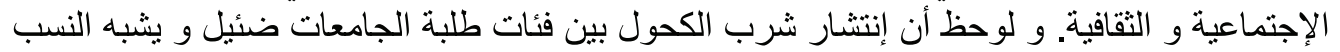

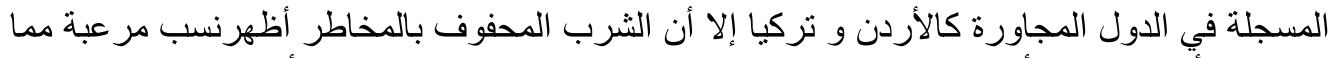

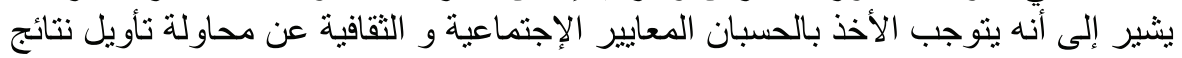
إختبار الكثفعنإضطر اباتتعاطيالكحول.

Keywords: Alcohol Use Identification Test, Risky drinking patterns, Alcohol consumption 


\section{Introduction}

Globally, alcohol use disorders affect more than 76.3 million out of two billion people who consume alcohol. ${ }^{1}$ In 2004, the World Health Organization (WHO) estimated that alcohol was responsible for 2.5 million deaths in the world each year. ${ }^{2}$ Alcohol consumption is the world's third largest risk factor for disease and disability and was responsible for 3.8\% of global mortality $(6.3 \%$ in men and $1.1 \%$ in women) in $2011 ., 3,5$ Additionally, alcohol-attributable deaths occur relatively early in life thus resulting in losing many years due to premature mortality; and are often very disabling.

Alcohol consumption incidence in the Eastern Mediterranean Region is the lowest compared to other World Health Organization regions as alcohol consumption is prohibited in Islam and is officially banned in most Muslim countries. However, the main problem is the absence of official trusted statistics related to alcohol (and substance) use in these countries. ${ }^{5,6}$

Alcohol is not banned in Iraq and there are shops that sell alcohol for bars and night clubs. However, alcohol consumption was banned for a few years in the 1990s and after the 2003 invasion, alcohol remains difficult to buy especially in religious cities. These factors have made and continue to make medication abuse more common and more socially acceptable. ${ }^{7}$ There are presently a few studies about substance use in Iraq, which have mostly investigated smoking. Alcohol consumption is officially permitted in Iraq, although it is religiously prohibited by Islam; the religion of the majority. ${ }^{8}$ One small household survey in 2004 reported alcohol consumption incidence at $5.4 \% .{ }^{9}$ A national household survey ${ }^{10}$ reported substance (alcohol and illicit drug) use disorders incidence rate as $0.9 \%$.

For assessment of alcohol consumption and alcohol use disorders, a long-standing debate continued about the indices used for determining its harm. The development of AUDIT by WHO was a great success in this respect. AUDIT was developed by WHO in 1989 as a simple method of screening for excessive drinking through a collaborative project performed in primary healthcare facilities in six countries. ${ }^{11}$ It showed high reliability as Cronbach's $\alpha$ was calculated at 0.78 for consumption, 0.84 for drinking problems and 0.94 for the entire scale in the US. ${ }^{12}$ It was found to be valid to identify participants with alcohol-related problems with a sensitivity of $94 \%$ and a specificity of $92 \%$ in a college student sample in Nigeria. ${ }^{13}$ A cut-off value of eight, yields a sensitivity of 0.90 and a specificity of 0.80 .

However, the socio-cultural factors are important determinants of predictors of alcohol consumption trends, attitudes and beliefs. The rationale for this study was to explore the possible bias resulting from application of the 
same standard questions used in AUDIT questionnaire in a Muslim country (i.e.Iraq).

\section{Material and Methods}

Objectives: Main objective is to determine potential bias in AUDIT application in a Muslim community. In addition, the study is aimed to find the prevalence of alcohol consumption among Karbala/ Iraq University students and their associations with participants' demography and other related predictors to help in forwarding proper control programmes.

Ethical considerations: Ethical approval was obtained from Karbala University and all responses were anonymous. Besides, the students were informed that completing the questionnaire meant participating in the survey.

Participants: In 2010, a total of 5446 students in Karbala/Iraq University participated voluntarily in a cross-sectional study. A random sample of the study halls was selected where the students were asked to fill a questionnaire during lecture hours.

Measures and tools: The questionnaire included questions about demographic variables in addition to substance (tobacco, alcohol and illicit drug) use. AUDIT was used for alcohol consumption in one of the sections of the questionnaire. The study was part of a larger project and the results of other questionnaires will be published later.

Procedure: The study was conducted in mid October-December 2010. In each of the eleven colleges, students were visited in the lecture halls which were almost fixed. Handouts were distributed and an introductory speech was given by the researcher stressing the voluntary participation, confidentiality and anonymity of the study.

Analysis: Data was input into a pre-designed database with data management and analysis using standard statistical tools (SPSS-17). Data input validity was checked through re-entering $10 \%$ of the questionnaire forms and internal reliability was checked between different questions. Descriptive analysis was performed to find rates and percentages of the study variables. Response rates were estimated and analysed to determine non-respondents' trends. Determining associations were followed depending on chi-squared test as most variables were categorical with regression analysis at a significant level of $p<0.001$. The stringent level was chosen to compensate for the multiple analyses conducted. 


\section{Results}

The response rate for the questions in this section was high $(78-100 \%)$, among the total participants $(\mathrm{n}=5446)$ while the response rate of those who actually consumed alcohol was higher (86-89\%).

The gender distribution showed almost equal numbers and the demographic characteristics of the sample are shown in Table 1.

Table 1. The demographic distribution of Karbala University students in 2010

\begin{tabular}{|c|c|c|c|c|}
\hline \multicolumn{2}{|l|}{ Variable } & Category & Frequency & Percentage \\
\hline \multicolumn{2}{|l|}{ Gender } & Male & 2496 & 45.8 \\
\hline \multicolumn{2}{|l|}{ Female } & 2950 & 54.2 & \\
\hline \multicolumn{2}{|l|}{ Age category } & $17-20$ Years & 2226 & 40.9 \\
\hline \multicolumn{2}{|l|}{$21-25$ Years } & 2444 & 44.9 & \\
\hline \multirow{2}{*}{\multicolumn{2}{|c|}{ over 25 Years }} & 509 & 9.3 & \\
\hline & & 267 & 4.9 & \\
\hline \multicolumn{5}{|l|}{ Missing } \\
\hline \multirow[t]{11}{*}{ College } & \multirow[t]{4}{*}{$\begin{array}{l}\text { Humanities } \\
\text { and Social } \\
\text { Sciences }\end{array}$} & $\begin{array}{l}\text { College of Adminis- } \\
\text { tration and Econom- } \\
\text { ics }\end{array}$ & 1673 & 30.7 \\
\hline & & College of Education & 831 & 15.3 \\
\hline & & College of Law & 544 & 10.0 \\
\hline & & $\begin{array}{l}\text { College of Islamic } \\
\text { Sciences }\end{array}$ & 339 & 6.2 \\
\hline & \multirow{7}{*}{$\begin{array}{l}\text { Natural } \\
\text { Sciences }\end{array}$} & College of Science & 791 & 14.5 \\
\hline & & College of Agriculture & 198 & 3.6 \\
\hline & & College of Medicine & 236 & 4.3 \\
\hline & & $\begin{array}{l}\text { College of Veterinary } \\
\text { Med }\end{array}$ & 121 & 2.2 \\
\hline & & College of Pharmacy & 188 & 3.5 \\
\hline & & $\begin{array}{l}\text { College of Engineer- } \\
\text { ing }\end{array}$ & 365 & 6.7 \\
\hline & & $\begin{array}{l}\text { College of Sport Edu- } \\
\text { cation }\end{array}$ & 160 & 2.9 \\
\hline
\end{tabular}




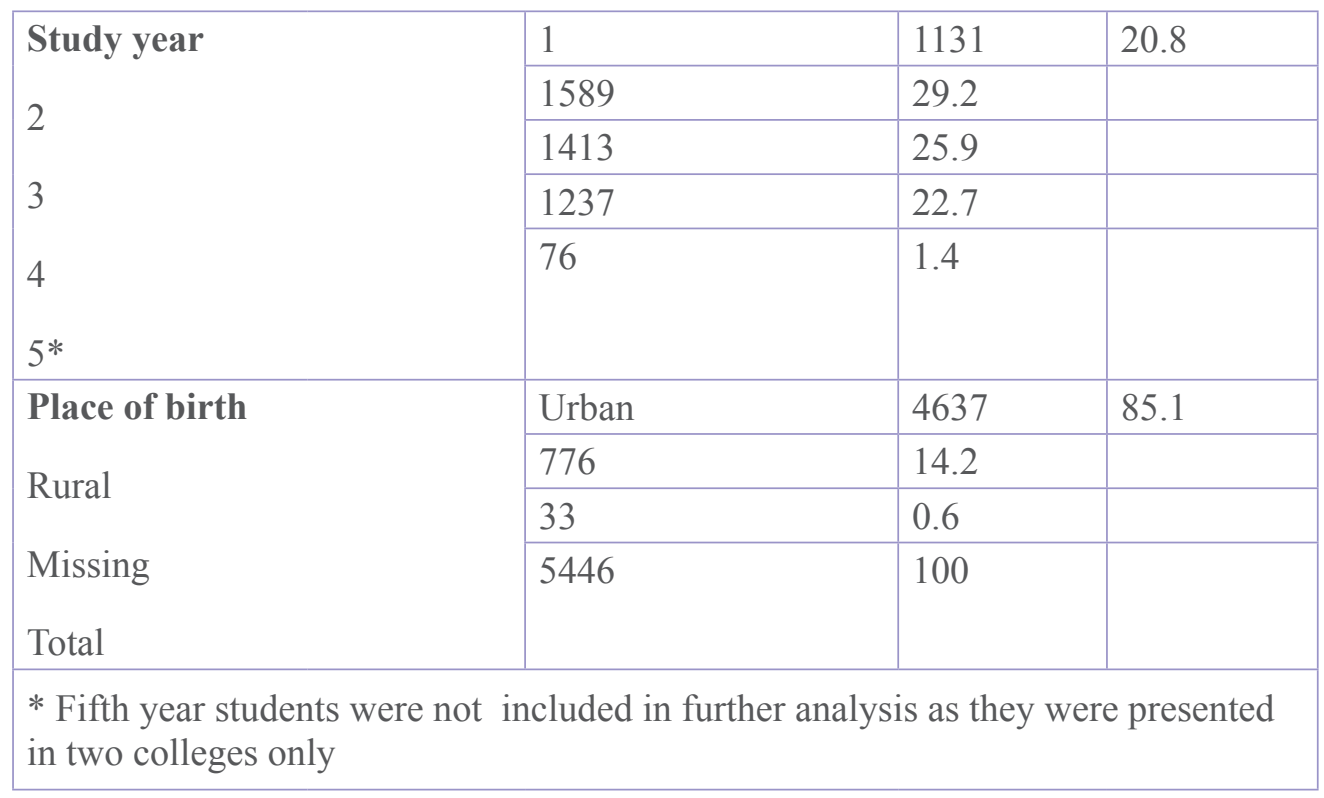

The internal reliability of the ten questions in the alcohol section (AUDIT) was tested and Cronbach's $\alpha$ was .663. The least consistent was the question about guilt and when this was removed the internal reliability increased (Cronbach's $\alpha=.726$ ).

The total number of students who reported consumption of any alcoholic beverage was 116 (103 males and 13 females). The consumption of alcohol was very low $(2.2 \%)$ among the total number of those who answered the questionaire. This situation is not alarming in a country where Muslim population is high.

Under-reporting might have contributed to this low prevalence within the social context surveyed, especially for females. Under-reporting is unpredictable and cannot be calculated in cross-sectional studies. However, low reporting in a national survey is common. ${ }^{10}$ The outstanding feature was that more than half $(56 \%)$ of those who consumed alcohol were at risk (AUDIT score $\geq 8$, Table 2$)$. The mean AUDIT score $(9.79, \mathrm{SD}=6.19)$ was also high, suggesting that this sample consisted of frequent alcohol users and therefore, experienced alcohol use problems. Half $(50 \%)$ of those who consumed alcohol reported having previous alcohol abuse problems (Table 2). 
Table 2. Alcohol drinking risk level frequency distribution among those who consumed alcohol $(n=116)$ among Karbala

University students in 2010

\begin{tabular}{|c|c|c|c|}
\hline Variable & Categories & $\begin{array}{l}\text { Frequen- } \\
\text { cy }\end{array}$ & Percentage \\
\hline \multirow{5}{*}{$\begin{array}{l}\text { Alcohol consumption } \\
\text { level according to AU- } \\
\text { DIT score (in brackets) }\end{array}$} & Sensible drinking $(<8)$ & 33 & 44.0 \\
\hline & Hazardous drinking (8-15) & 27 & 36.0 \\
\hline & Harmful drinking (16-19) & 8 & 10.7 \\
\hline & Possible dependence $(\geq 20)$ & 7 & 9.3 \\
\hline & Total & $75^{*}$ & 100.0 \\
\hline \multirow{6}{*}{$\begin{array}{l}\text { Number of Standard } \\
\text { Units of alcohol con- } \\
\text { sumed on a typical day } \\
\text { of drinking }\end{array}$} & 1 to 2 units & 71 & 61.2 \\
\hline & 3-4 units & 22 & 19.0 \\
\hline & 5-6 units & 11 & 9.5 \\
\hline & 7-9 units & 5 & 4.3 \\
\hline & 10 or more units & 7 & 6.0 \\
\hline & Total & 116 & 100.0 \\
\hline \multirow{5}{*}{$\begin{array}{l}\text { Frequency of alcohol } \\
\text { drinking }\end{array}$} & Once monthly or less & 40 & 40.8 \\
\hline & 2-4 times a month & 26 & 26.5 \\
\hline & 2-3 times a week & 12 & 12.2 \\
\hline & 4 or more times a week & 20 & 20.4 \\
\hline & Total & 98 & 100 \\
\hline \multirow{5}{*}{$\begin{array}{l}\text { Frequency of drinking } \\
6 \text { Units or more on one } \\
\text { occasion }\end{array}$} & Less than monthly & 11 & 22.0 \\
\hline & Monthly & 16 & 32.0 \\
\hline & Weekly & 14 & 28.0 \\
\hline & Daily or almost daily & 9 & 18.0 \\
\hline & Total & 50 & 100.0 \\
\hline \multicolumn{4}{|c|}{ The cut off point for risky alcohol consumption for AUDIT questions $\geq 8$} \\
\hline
\end{tabular}

More than half (54.4\%) of those who consumed alcohol reported guilt and almost a similar number (49.1\%) reported that others were concerned about their drinking.

Alcohol consumption was significantly high among male smokers and those who study in the evening and the numbers increased with age. It was higher among students in the Colleges of Humanities and Social Sciences than those in the Natural Science College.

Alcohol consumption was significantly associated with trauma, smoking 
$(\mathrm{OR}=7.16)$, male gender $(\mathrm{OR}=10.52)$, SHS exposure (more with higher SHS exposure) and students who take evening classes (OR of day time students $=0.51$ ) and the reasons are believed to be socio-cultural factors. When smoking output variables were excluded to elaborate any possible effect caused by the basic variables, the model showed that the consumption of alcohol was significantly higher for males than for females $(\mathrm{OR}=10.52)$ but higher for students with increased exposure to smoking. The incidence of alcohol consumption was lower for day time students than for those students who took evening classes $(\mathrm{OR}=0.51$, Table 3$)$. Smoking was excluded because it was the only shown significant variable.

Table 3. Logistic regression model results of alcohol consumption with all potential variables without smoking output variables (reference category: those who did not consume alcohol)

\begin{tabular}{|l|l|l|l|}
\hline \multicolumn{2}{|l|}{ Variable } & $\begin{array}{l}\text { Odds ratios } \\
\text { Wild test } \\
\text { significance } \\
\text { Gender (reference category: } \\
\text { female) }\end{array}$ & $\begin{array}{l}\text { Likelihood } \\
\text { Ratio signif- } \\
\text { icance }\end{array}$ \\
\hline $\begin{array}{l}\text { Type of the study (reference } \\
\text { category: evening study group) }\end{array}$ & $0.51(0.32-0.82)$ & $<0.001$ \\
\hline $\begin{array}{l}\text { Days exposed to smoking (refer- } \\
\text { ence category: those exposed to } \\
\text { smoke on all 7 days in the past } \\
\text { week) }\end{array}$ & $\begin{array}{l}\text { (1) } \\
\text { 0 day smoke exposure }\end{array}$ & 0.005 \\
\hline 1-2 days smoke exposure & $0.32(0.18-0.57)$ & $<0.001$ & $<0.001$ \\
\hline 3-4 days smoke exposure & $0.35(0.16-0.75)$ & 0.007 & \\
\hline 5-6 days smoke exposure & $0.19(0.05-0.79)$ & 0.023 & \\
\hline $\begin{array}{l}\text { Model fitting Chi-sq (6) }=101.73, \mathrm{P}<0.001 \\
\text { Goodness of fit probability Pearson Chi-sq (2795) }=2850.88, \mathrm{P}=0.226\end{array}$ \\
\hline
\end{tabular}




\section{Discussion}

Alcohol consumption levels found in this study were consistent with those conducted previously. Al-Hasnawi et a $1^{10}$ reported in a national household survey that the incidence of alcohol abuse was $0.7 \%$ while alcohol dependence was $0.2 \%$ in $2006 / 2007$. Alcohol consumption rate was $5.4 \%$ (5.4\% for males and $0.0 \%$ for females) among households in a northern city in Iraq (Duhok) in 2003-2004. The reason behind higher consumption rate than the present study is believed to be the age of the participants and inclusion of Christians in the sampling (about 5\%). ${ }^{9}$

Similarly, a few studies have been done in the neighbouring countries. However, the rates reported in most reviews were higher than this study probably due to socio-cultural differences and use of different methodology. A report from the EMRO countries in 2006 showed that $22 \%-50 \%$ of university students have consumed alcohol has and the numbers have increased especially in vulnerable pockets who usually consumed in a hazardous pattern. ${ }^{14}$ Lifetime consumption rates were: (17\%) in Jordan, ${ }^{15} 7-22 \%$ in Egypt, ${ }^{16} 6 \%$ in $\operatorname{Iran}^{17}$ and $42 \%$ in Israel. ${ }^{18}$ Much higher rates were reported in the developed countries: $(>80 \%)$ in Europe $^{19}$ and $(85 \%)$ in the US. ${ }^{20}$

The socio-cultural context in Karbala as a religious place is a reason for low numbers of alcohol consumption especially among females. Females were $11 \%$ among those who consumed alcohol. No females consumers were reported from the northern city in Iraq (Duhok). ${ }^{79}$ A higher incidence may be reported if the study was conducted in another city in Iraq such as Baghdad. However, it was not possible to conduct a survey in Baghdad due to safety reasons.

In spite of the low incidence, the rate of risky consumption (AUDIT score $\geq 8$ ) was high $(56 \%)$, when compared with the rate of $7.4 \%$ reported among medical students in Turkey, ${ }^{21}$ and $8.5 \%$ of adults in the United States. ${ }^{22}$ Only a minority (15\%) met the criteria for an AUD across 36 medical schools surveyed in the United States in 2000. ${ }^{22}$

A study in the US analysed two decades of surveys about alcohol consumption among undergraduate students and concluded that alcohol consumption rates were very high $(>80 \%)$ and approximately two out of five American college students were heavy drinkers, defined as having had five or more drinks daily for a period of two weeks. ${ }^{23}$

The significant predictors of alcohol consumption were consistent with those found in studies conducted in neighbouring countries and in developed countries. Gender difference is mainly related to socio-cultural factors where male consumers are more accepted in society, while association with smoking was reported by many studies in Iraq, ${ }^{24}$ and other countries. ${ }^{21,25,26}$ 
The higher rates among the evening study groups may be due to their older age or their socio-economic level.

\section{AUDIT use in Muslim countries}

It is important to consider the socio-cultural environmental effect during the analysis of the AUDIT questionnaire in Muslim countries. The socio-cultural context in Muslim countries drives those who consume alcohol to express a high rate of guilt and reports that others cared about their drinking; which is not the case in non-Muslim contexts. These two indicators could have a profound effect on AUDIT score and may lead to a "false" positive AUDIT score. Although a large number of published studies compared AUDIT score validity in different socio-cultural environments, 13,27,28,29,30,31,32 none of the reviews reported this weakness. A higher number of males had a positive AUDIT score in this study and this was similar to other reported studies in the neighbouring countries. 21

Subjects of study and smoking among males were significant reasons of alcohol consumption in many reviewed studies. ${ }^{21.25}$ The gender specific incidence is the expected norm given the socio-cultural context in the EMRO countries. The gateway theory anticipates association with smoking as explained in section 8.5.9. $33,34,35,36,37,38,39$

The risk factors associated with alcohol consumption by high school students in Iran were: old age $(\mathrm{OR}=1.55)$, having a general risk taking behaviour $(\mathrm{OR}=1.70)$, smoking (Nicotine dependent $\mathrm{OR}=3.70)$, self destructive nature $(\mathrm{OR}=1.22)$, high socio-economic level $(\mathrm{OR}=1.62)$ and life time use of illicit drugs $(\mathrm{OR}=5.72)$. Research revealed that incidence of alcohol use and drug abuse was in the increase among secondary school students i.e.10.1\% and $2.2 \%$ for alcohol use and drug abuse, respectively. However, a clear limitation in this study was that the researchers considered non reporting as 'never having used drugs' with no clear explanation for this miscalculation. ${ }^{25}$

\section{References}

1. World Health Organization. Global Status Report on Alcohol Geneva, Switzerland: 2004.

2. World Health Organization. Global strategy to reduce harmful use of alcohol. Italy: 2010.

3. World Health Organization. Global health risks: Mortality and burden of disease attributable to selected major risks. France: 2009. 
4. World Health Organization. Global health risks: Mortality and burden of disease attributable to selected major risks report. France: 2009.

5. World Health Organization. Global status report on alcohol and health. Geneva, Switzerland: 2011.

6. Radovanovic Z, Pilcher CWT, Al-Nakib T, Shihab-Eldeen A. On substance abuse in Kuwait (1992-1997): Evidence from toxicological screening of patients. Journal of Substance Abuse. 2000;12(4):363-71. Doi: http://dx.doi.org/10.1016/S0899-3289(01)00057-8

7. Al-Hasnawi SM. Substance Use Disorders in Iraq. Addiction. 2005;100:1567-9.

8. United Nations Office for the Coordination of Humanitarian Affairs. The Integrated Regional Information Networks (IRIN). Iraq country profile: United Nations Office for the Coordination of Humanitarian Affairs. The Integrated Regional Information Networks (IRIN). 2012. Available from: http://www.irinnews.org/country/iq/iraq.

9. Abdulrahman M, Abdulghany, A. Kurdistan Regional Government. Ministry of Health. Duhok Health Diroktorate. Final report on non-communicable diseases risk factors survey in Duhok District. 2004.

10. Alhasnawi S, Sadik S, Rasheed M, Baban A, Al-Alak MM, Othman AY, et al. The prevalence and correlates of DSM-IV disorders in the Iraq Mental Health Survey (IMHS). World Psychiatry. 2009;8(2):97109.

11. Babor TF, Higgins-Biddle, J.C., Saunders, J.B., Monteiro, M.G. The Alcohol Use Disorders Identification Test: Guidelines for use in primary care. Geneva, Switzerland: 2001.

12. O'Hare T, Sherrer MV. Validating the Alcohol Use Disorder Identification Test With College First-Offenders. Journal of Substance Abuse Treatment. 1999;17(1):113-9.

Doi: http://dx.doi.org/10.1016/S0740-5472(98)00063-4

13. Adewuya AO. Validation of the alcohol use disorders identification test (audit) as a screening tool for alcohol-related problems among Nigerian university students. Alcohol and Alcoholism. 2005 NovDec;40(6):575-7.

PubMed PMID: 16115823.

Doi: http://dx.doi.org/10.1093/alcalc/agh197 
14. World Health Organization. East Mediterranean Regional Office. Public health problems of alcohol consumption in the region. Cairo, Egypt: 2006.

15. Suleiman RA, Shareef, M, Kharabsheh,S,Abu Danoon, M. Substance Use Among University and College Students in Jordan. Arab Journal of Psychiatry (AJP). 2003;14(2):94-105.

16. Soueif MI, Hannourah MA, Darweesh ZA, El-Sayed AM, Yunis FA, Taha HS. The use of psychoactive substances by female Egyptian university students, compared with their male colleagues on selected items. Drug and Alcohol Dependence. 1987;19(3):233-47.

Doi: http://dx.doi.org/10.1016/0376-8716(87)90043-3

17. Ahmadi J, Maharlooy N, Alishahi M. Substance abuse: Prevalence in a sample of nursing students. Journal of Clinical Nursing. 2004;13(1):60-4.

Doi: http://dx.doi.org/10.1046/j.1365-2702.2003.00841.x

18. Brook U, Feigin R, Sherer M, Geva D. Prevalence, attitudes and knowledge of high school pupils towards drugs and other addictions: implications for school health education in Israel. Patient Education and Counseling. 2001;43(2):199-204.

Doi: http://dx.doi.org/10.1016/S0738-3991(00)00163-4

19. Wicki M, Kuntsche E, Gmel G. Drinking at European universities? A review of students' alcohol use. Addictive Behaviors. 2010;35(11):913-24. Doi: http://dx.doi.org/10.1016/j.addbeh.2010.06.015

20. Johnston LD, O’Malley PM, Bachman JG, Schulenberg JE. Monitoring the Future national survey results on drug use, 1975-2011. Volume II.College students and Adults ages 19-50. 2012 Contract No.: NIH Publication No. 09-7402.

21. Akvardar Y, Demiral Y, Ergor G, Ergor A. Substance use among medical students and physicians in a medical school in Turkey. Social Psychiatry and Psychiatric Epidemiology. 2004;39(6):502-6.

Doi: http://dx.doi.org/10.1007/s00127-004-0765-1

22. Falk D, Yi, H.-y., Hiller-Sturmhöfel, S. An Epidemiologic Analysis of Co-Occurring Alcohol and Drug Use and Disorders: Findings From the National Epidemiologic Survey of Alcohol and Related Conditions (NESARC). Alcohol Research and Health. 2008;31(2):100-10. 
23. O'Malley PM, Johnston LD. Epidemiology of alcohol and other drug use among American college students. J Stud Alcohol Suppl. 2002 Mar;(14):23-39.

PubMed PMID: 12022728. Epub 2002/05/23. eng.

Doi: http://dx.doi.org/10.15288/jsas.2002.s14.23

24. Al Mousawi A. The Prevalence of Smoking Among Karbala/Iraq University Students in Iraq in 2005. Tobacco Use Insights. 2014;7:9-14. Doi: http://dx.doi.org/10.4137/TUI.S12238

25. Mohammadpoorasl A, Fakhari A, Rostami F, Vahidi R. Predicting the initiation of substance abuse in Iranian adolescents. Addictive Behaviors. 2007;32(12):3153-9.

Doi: http://dx.doi.org/10.1016/j.addbeh.2007.07.014

26. Baba TA, Ganai AM, Qadri SS, Margoob MA, iqbal qm, khan za. An Epidemiological study on Substance Abuse among college students of north India (Kashmir valley). Int J Med Sci Public Health. 2013;2(3):540-5.

Doi: http://dx.doi.org/10.5455/ijmsph.2013.080420131

27. Santis R, Garmendia ML, Acu-a G, Alvarado ME, Arteaga O. The Alcohol Use Disorders Identification Test (AUDIT) as a screening instrument for adolescents. Drug and Alcohol Dependence. 2009;103(3):155-8.

Doi: http://dx.doi.org/10.1016/j.drugalcdep.2009.01.017

28. Kawada T, Inagaki H, Kuratomi Y. The alcohol use disorders identification test: reliability study of the Japanese version. Alcohol. 2011;45(3):205-7.

Doi: http://dx.doi.org/10.1016/j.alcohol.2010.08.012

29. Zaidan Z, Dorvlo A, Viernes N, Al-Suleimani A, Al-Adawi S. Hazardous and Harmful Alcohol Consumption Among Non-Psychotic Psychiatric Clinic Attendees in Oman. International Journal of Mental Health and Addiction. 2007;5(1):3-15.

Doi: http://dx.doi.org/10.1007/s11469-006-9046-4

30. Almarri TSK, Oei TPS, Amir T. Validation of the Alcohol Use Identification Test in a Prison Sample Living in the Arabian Gulf Region. Substance Use \& Misuse. 2009;44(14):2001-13.

PubMed PMID: 20001691.

http://dx.doi.org/10.3109/10826080902848533 
31. Neumann T, Spies C. Use of biomarkers for alcohol use disorders in clinical practice. Addiction. 2003;98:81-91.

Doi: http://dx.doi.org/10.1046/j.1359-6357.2003.00587.x

32. Reinert DF, Allen JP. The Alcohol Use Disorders Identification Test (AUDIT): A Review of Recent Research. Alcoholism: Clinical and Experimental Research. 2002;26(2):272-9.

Doi: http://dx.doi.org/10.1111/j.1530-0277.2002.tb02534.x

33. Beenstock M, Rahav G. Testing Gateway Theory: do cigarette prices affect illicit drug use? Journal of Health Economics. 2002;21(4):679-98. Doi: http://dx.doi.org/10.1016/S0167-6296(02)00009-7

34. Degenhardt L, Dierker L, Chiu WT, Medina-Mora ME, Neumark Y, Sampson N, et al. Evaluating the drug use "gateway" theory using cross-national data: Consistency and associations of the order of initiation of drug use among participants in the WHO World Mental Health Surveys. Drug and Alcohol Dependence. 2010;108(1-2):84-97.

Doi: http://dx.doi.org/10.1016/j.drugalcdep.2009.12.001

35. Levy DE, Biener L, Rigotti NA. The natural history of light smokers: A population-based cohort study. Nicotine \& Tobacco Research. 2009 Feb;11(2):156-63.

36. Lindsay GB, Rainey J. Psychosocial and Pharmacologic Explanations of Nicotine's "Gateway Drug” Function. Journal of School Health. 1997;67(4):123-6.

Doi: http://dx.doi.org/10.1111/j.1746-1561.1997.tb03430.x

37. Torabi MR, Bailey WJ, Majd-Jabbari M. Cigarette smoking as a predictor of alcohol and other drug use by children and adolescents: evidence of the "gateway drug effect". The Journal of school health. 1993;63(7):302-6.

Doi: http://dx.doi.org/10.1111/j.1746-1561.1993.tb06150.x

38. Anthony JC, Petronis KR. Early-onset drug use and risk of later drug problems. Drug and Alcohol Dependence. 1995;40(1):9-15.

Doi: http://dx.doi.org/10.1016/0376-8716(95)01194-3

39. Swadi H. Individual risk factors for adolescent substance use. Drug and Alcohol Dependence. 1999;55(3):209-24.

Doi: http://dx.doi.org/10.1016/S0376-8716(99)00017-4 